\title{
The Institutional of Local Community and Stratification of Land Ownership in Surrounding Community Forests in Bogor
}

\author{
Tatan Sukwika $^{1 *}$, Dewi Nurhayati Yusuf ${ }^{2}$, Ichsan Suwandhi $^{3}$ \\ ${ }^{1}$ Environmental Engineering, Faculty of Engineering, Sahid University, Kampus Soepomo, Jakarta, Indonesia 12870 \\ ${ }^{2}$ Soil Sciences, Faculty of Agriculture, Haluoleo University, Kampus Hijau Bumi Tridharma, Kendari, Indonesia 93232 \\ ${ }^{3}$ Forestry Engineering, School of Life Sciences and Technology ITB, Kampus Jatinangor, Sumedang, Indonesia 45363
}

Received December 6, 2019/Accepted March 5, 2020

\begin{abstract}
Management of forest resources cannot be separated from the character attributes of the community. In the arena of community forest action, access to forest resources, which is a people's livelihood, is an important element. The study aimed to analyze the performance of the local community attributes towards community welfare and examine the stratification of community land ownership. This research was carried out in the qualitative descriptive analysis. The results of the analysis showed that $41.56 \%$ of the community forest farming groups classified as land-owners. Based on the strata of land ownership showed that $70 \%$ in the third strata, which was land-ownership of less than 0.5 ha. This study concluded that the institutional of local community was relatively low because not effective in regulating community behavior. These indicated by the low performance achieved on the welfare of the community, the low ownership of the area of arable land, and the level of welfare of the local community falls into the category of poor and low community education.
\end{abstract}

Keywords:community attributes, community forests, land stratification, qualitative-descriptive analysis

*Correspondence author, email:tatan.swk@gmail.com

\section{Introduction}

The community forest is one of the resources that provide significant benefits for human welfare, both directly and indirectly benefits. Direct benefits such as the provision of wood, supporting the availability of food and spices, herbal medicine, and animals. Indirect benefits of community forests such as protecting and regulating water flow, land conservation, forest protection, and prevention of erosion. The benefits mentioned above can be optimal if aspects of the availability of land around community forests in their management can provide a positive influence on welfare (social and economic) and environment (ecology) in a sustainable manner.

The form of cooperation in managing forest resources cannot be separated from the character attributes of the community itself. In fact, in the arena of community forest action, access to forest resources is considered a source of community livelihood (Sukwika et al., 2018) and is an important element in creating group collaboration (Ratner et al., 2013; Sukwika, 2018a). Ostrom (2005) stated that some communities that influence the arena of action include: (1) behavioral values recognized by the community; (2) the level of homogeneity of people's life preferences; and (3) the size and composition of the community.
The pattern of land tenure in community forests consists of three patterns, namely private land, family-owned land, and leased land. (1) Private land is the land that belongs to one person, and he manages the land. (2) Family-owned land is a land in one stretch, derived from the legacy of deceased parents, but has not been distributed to each of the heirs (children). For the land, they usually manage and use the land together or take turns. If the land wants to be sold, all heirs must approve it. (3) The leased land is a land that is leased to someone to be managed or utilized for commercial purposes.

In community forests, there are various initiatives, forms and management systems. Based on its management initiatives, there were three initiators of community forest development, namely: land-owners, the government and the private sector. Community forests built at the initiative of land-owners were found in Bogor. The owner takes the initiative to plant an annual crop as a source of income for his family. In the community forest model such as this aspect of species selection, capital development and technology input depends entirely on the desire, level of knowledge, capital ownership and the environment that influences it. According to Suharti (2001), environmental factors such as the success of others in developing a commodity become the reasons often raised by community forest farmers in choosing the 
type of crop.

The community forest model in Bogor is a traditional community forest, which is developed from generation to generation by several community groups. Its main characteristic is management with agroforestry patterns and minimal technological input. It is in line with the results of a study by Sukwika et al. (2016) and Sukwika (2018a), which stated that community forest management in Bogor was still traditionally carried out by the people with minimal silvicultural techniques and management so that the results and sustainability were not optimal.

The community forest developed by the government on community-owned land, functions as a demonstration plot for land rehabilitation, and aims to increase land productivity. This community forest development utilizes the government budget through the stages of land preparation, planting, and maintenance activities. In addition to building land physically, there is also preparation of socialization for beneficiary farmer groups in the form of management and technical training as well as mentoring by extension workers. BKP5K (2014) stated that farmer groups in the community forest area of Bogor were classified into four groups, namely beginner, intermediate, advanced, and primary groups. Community forests developed by the private sector are scarce in Bogor. The purpose of this study is explaining the local community institution and reviewing the stratification of community land ownership in community forest areas.

\section{Methods}

Research location and data collection This research was conducted in the Bogor community forest area. The selection of research locations and respondents was made by purposive sampling with the consideration that the location had community forest areas, and respondents had been declared capable of managing their forests in groups. The research method was a survey using a questionnaire with data collection techniques, including observation, interviews, and documentation. Data analysis was performed in a descriptive qualitative manner.

Data used to carry out analysis of local institutions include (1) Secondary data, including biophysical/material conditions, community attributes, and types of land ownership and utilization. These biophysical data on community forests collected from BPS (central bureau of statistics) in Bogor, village offices and district offices, research results, and other publication materials. (2) Primary data obtained from farmers, community leaders, local government agencies, government officials in agricultural and forestry extension services, agroforestry managers, and the results of field triangulation in community forests. Attributes include socio-economic data including demographics and monographs, farmer groups, land ownership and control, actors interacting in the field, forest management rules, local community norms/rules, and coordination.

The framework elaborated below builds on the institutional analysis and development (IAD) model (Oakerson, 1992; Ostrom, 2005; Poteete et al., 2010). Ratner et al. (2013) selected the IAD model as the foundation because it is highly adaptable, had been applied to a wide range of institutional analyses across different resource systems, and because it also enables an analysis of divergent outcomes, even if historically it has primarily been applied to understand the sources of cooperation.

Figure 1 explains the patterns of interaction between actors with dimensions of regulation and control. Therefore, the function and benefits of forests as community forest areas

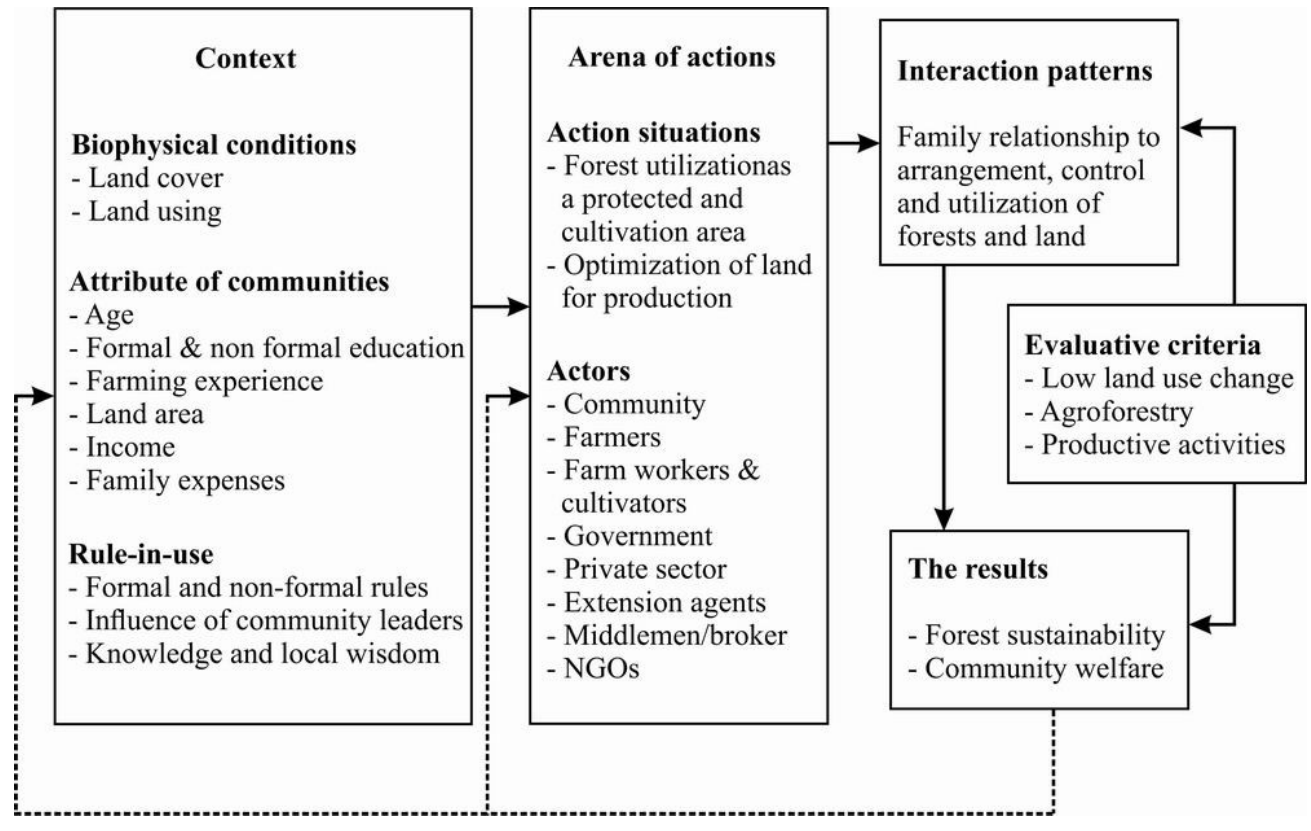

Source : Adopted from Ostrom (2005) and Di Gregorio et al. (2008), with modification

Figure 1 Arena of action for community forest management action. 
can be preserved, and the improvement of community welfare can be achieved. The criteria used to assess the results were the low of land-use conversion, extensive forest cover (agroforestry), and productive activities carried out by communities in the area surrounding community forests.

\section{Results and Discussion}

Biophysical conditions: Land cover In 2012, the condition of land cover in Bogor forest consisted of production forests covering an area about 16,945.40 ha, rice fields $6,260.46$ ha, grazing fields $980.44 \mathrm{ha}$, and fields/moorings covering an area about 4,833.51 ha. In 2015 there has been a change in land cover in the form of production forests, which decreased by $0.31 \%$ to $16,848.60$ ha and rice fields, which also decreased by $2.06 \%$ to $5,617.24$ ha. In the same year, there was an increase in settlement to $2,638.45$ ha, and fields/moorlands increased to 5,058.33 ha (Sukwika et al., 2016; Sukwika et al., 2018). From 2012 to 2015, there had been a reduction in community forest cover with an average annual rate of $0.19 \%$ and rice fields of $3.42 \%$, while the rate of increase in settlements was 6.56\% (Sukwika, 2018a).

Throughout 2010, part of the state forest area in National Park of Mountain Gede-Pangrango in Bogor has been rehabilitated by the forest, and since the issuance of Presidential Regulation Number 54/2008, the Perhutani (state-owned enterprises) has banned logging activities on pine forests (Pinus mercusii), but only carried out activities to protect, rehabilitate and extract forest products in the form of pine sap. Whereas in community forests, land cover conditions outside the forest area have increased. Even though land ownership and transfer of arable land occur to the community outside Bogor, especially from DKI-Jakarta, there is very little land converted to non-forestry. Cultivating farmers who are employed generally are previous landowners or residents who live around community forest areas, making it easier to rehabilitate land vegetatively by planting new trees or technically by making infiltration wells. This mutualism relationship occurs because local people need land that can be processed to increase their income, while landowners outside the community forest area need security over their land rights.

Land-use Community forest in Bogor has an area of $16,945.40$ ha, around 13,314.02 ha of land-use in the form of plantations forest, rice fields, plantations and agroforestry, seasonal crops, fisheries, livestock, and settlements. The characteristics of land use in community forests are affected by commodities but are not influenced by the planting system and land area, and land status (Table 2), land use, or farming motivation.

Commodities in community forests are dominated by forest plants, food crops, and horticulture (Table 3).

Table 2 Strata of land ownership rights and community forest farming community groups

\begin{tabular}{lcccc} 
& Comer & Propieter & Claimant & Autorized \\
Rights stratum & & & & \\
\hline $\begin{array}{l}\text { Access and withdraw } \\
\quad \text { Determine the form of } \\
\text { management }\end{array}$ & $\sqrt{ }$ & $\times$ & $1.39 \%$ & $7.03 \%$ \\
$\quad \begin{array}{l}\text { Determining participation/ } \\
\text { issuing other parties (exclusion) }\end{array}$ & $\sqrt{ }$ & $\times$ & \\
Can trade rights (alienation) & $41.56 \%$ & & & \\
\hline
\end{tabular}

Description: $\sqrt{ }=$ exists,$x=$ none.

Note: Farmworkers $(50.02 \%)$ do not have land ownership rights, therefore, they work in landowner groups, claimants, and users (authorized)

Table 3 Source of income of the respondent farmer's family from agricultural activities and additional activities in community forests

\begin{tabular}{|c|c|c|c|}
\hline \multirow[b]{2}{*}{ No } & \multirow[b]{2}{*}{ Source of income } & \multicolumn{2}{|c|}{ Income } \\
\hline & & $\begin{array}{l}\text { Monthly income } \\
\text { (USD month }^{-1} \text { ) }\end{array}$ & $\begin{array}{l}\text { Annual income } \\
\text { (USD year-1) }^{-1}\end{array}$ \\
\hline 1 & Sengon, mahogany, afrika & 67.20 & 806.40 \\
\hline \multicolumn{2}{|c|}{ Community Forest } & \multicolumn{2}{|c|}{$18.47 \%$} \\
\hline 2 & Farming vegetables and fruit crops & 48.55 & 582.60 \\
\hline 3 & Farm vegetables and fruit & 56.55 & 678.60 \\
\hline \multicolumn{2}{|c|}{ Agriculture } & \multicolumn{2}{|c|}{$28.89 \%$} \\
\hline 4 & Farm laborers & 31.00 & 372.00 \\
\hline 5 & Household stalls & 41.00 & 492.00 \\
\hline 6 & Sheep breeding 5-10 tails & 66.00 & 792.00 \\
\hline 7 & Fish ponds & 53.50 & 642.00 \\
\hline Etc. & & \multicolumn{2}{|c|}{$52.64 \%$} \\
\hline
\end{tabular}


Commodity selection influenced by suitability, wishes of landowners, following other farmers, easy to plant, easy to market, and variety of food for self-consumption. Forest farmers' resources include agriculture, fisheries, forests, grasslands. Farmer resources are input factors of production, which significantly affect production, including land, labor, and capital. Production influenced by the farming environment, technology, and social characteristics of farmers. According to (Mardikanto, 1996) socioeconomic factors in community forests are very influential on groups of farmers in working and innovating.

Land of business In 2015, land managed by community forest farmers covering an area of 30,162.62 ha, including land belonging to local communities and land owned by communities outside of community forests. Of the land area, $27,524.18$ ha $(91.25 \%)$ is land that can be cultivated by the community in the form of production forest land, dry rice fields and the remaining 2,638 ha $(8.75 \%)$ are land for grazing, ponds, and settlements. The number of people working in the community around the community forest is 26,030 households, therefore the average area cultivated by the community is 0.28 ha household ${ }^{-1}$ (BKP5K, 2014).

Community forest farmers who manage agricultural land can be classified into five groups, namely: (1) farmer-owners as well as cultivators of land, (2) farmer-owners whose land is cultivated by others, (3) farmers cultivating land belonging to others, (4) farmers as proficient who guard other people's land, and (5) farm laborers who work for other farmers. Based on land ownership status, the number of farmers who own and cultivate land is $40.94 \%$, farm labourers account for $49.81 \%$, and the number of farmers working on land belonging to other people and farmers (cultivator and farm workers) is $9.25 \%$ (BKP5K, 2014).

Based on the results of sampling of 70 community households of community forest farmer groups (KTHR), information was obtained that land ownership of farmer communities per household consisted of 0.17 ha of land owned, 0.47 ha of leased land, 0.45 ha of arable land, and 0.12 ha of borrowed land. The average land ownership and/or tenure is 0.36 ha. Based on stratification, the area of land managed by community forest farmers in Bogor is divided into 3 (three) strata groups, namely (1) stratum I: the area of community forest land is more than 1 ha; (2) stratum II: community forest land area 0.5 to $1 \mathrm{ha}$; and (3) strata III: community forest land area is less than 0.5 ha. As much as $70 \%$ of community forest farmers manage community forest land less than 0.5 ha (Figure 2).

From the results of field identification through a questionnaire survey, land ownership in Bogor's community forests was divided into four classifications (Schlager \& Ostrom, 1992), namely:

(1) The group of landowners (owner) is $41.56 \%$, consisting of landowners but not cultivating as much as $0.67 \%$ and the group of owners and cultivators of the land as much as $40.89 \%$. The landowner (owner) has the right to enter and utilize land resources (access and withdrawal), determine the form of management (management), determine participation/issue other parties (exclusion) and the right to trade land (alienation).
(2) The bounded owner group (proprietor) has no land ownership of $0 \%$.

(3) Claimants are $1.39 \%$ of farmers who work on land using a profit-sharing system.

(4) The authorized user group is 7.03\%. The smallholder groups have the right to enter and use land (access and withdrawal).

Outside the four groups are farm labourers (50.02\%) from community forest farmers, who do not have land ownership rights. The farmer group can only work and get wages from the owner, claimant, or authorized user. The strata of community forest land ownership rights in Bogor are presented in Table 2 .

The low level of community land tenure and the small income opportunities outside the forestry and agricultural sectors have resulted in the exploitation of land controlled through agricultural cultivation to meet their physical needs, without regard to soil and water conservation efforts. Food crop cultivation is done in monoculture. Planting a mixture of woody plants with food crops can reduce the productivity of food crops because they compete with each other in the site and lighting. With a narrow level of land ownership, there is no opportunity for the community to conserve land so that it has a negative impact on the management of community forest sustainability. The low level of control of land owned and cultivated land by local communities has resulted in a high economic dependence on the families of tenants/farm labourers to the landowners who live in and outside the community forest. Farm labourers, which account for $50.02 \%$ of the total number of farmers, do not have land assets to support their family's physical needs so they try to work in landowners (owner), claimants, and authorized land or work in the sector other or out of the territory.

The community conducts forestry activities (in the form of sengon, jabon, and afrika plants), agroforestry and agriculture (in the form of food crops, ornamental flowers, vegetables, fruits, and other perennials), fisheries (in the form of fish ponds), livestock (in the form of chickens and goats), and other productive cultivation activities. Among the cultivated forest plants, there are intercropping plants including corn, sweet potatoes, cassava, and other food

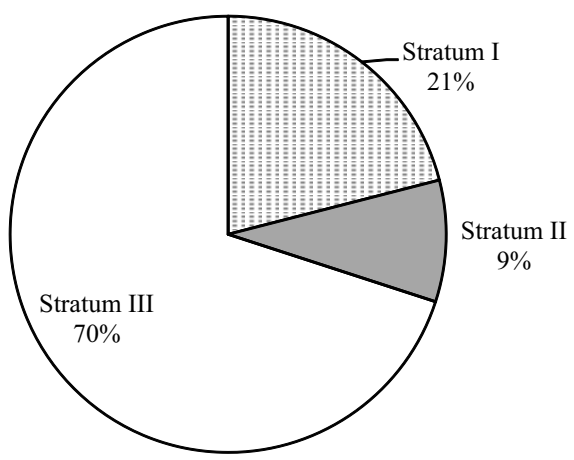

N-70: Average farmer's land area- 0.36 ha

Figure 2 Strata of land ownership by community forest farmers. 
crops. Crop productivity per season for rice reaches 6.3 tons $\mathrm{ha}^{-1}$, sweet potatoes 12 tons ha ${ }^{-1}$, cassava 17 tons ha ${ }^{-1}$, corn 4 tons $\mathrm{ha}^{-1}$, and peanuts 1.25 tons $\mathrm{ha}^{-1}$. Food crops, vegetables, and fruits that are cultivated by the community are not carried out intensively. The production of non-timber farmers is mostly for daily needs. While timber farmers' production, tends to be difficult to compete. According to Racevskis and Lupi (2006), competitively in business, rural, timberdependent community members are very concerned about the continued provision of both market and nonmarket forest outputs.

\section{Attributes of local communities in community forests The} population of forest village communities in Bogor in 2011 was 88,109 people and in 2015 there were 108,084 people with a density of 6.42 people ha ${ }^{-1}$, meaning that everyone inhabitant occupies every 0.17 ha in the community forest area in Bogor. The rate of population increase between 2011 and 2015 was $3.27 \%$ per year. The average number of family members is 4 people per family head. This population growth rate includes very high and exceeds the national population growth rate of $1.49 \%$. The high rate of population growth has resulted in higher land needs for settlements and land for businesses, on the other hand, the availability of land is increasingly limited. This condition encourages high changes in the function of yard/business land for settlements. According to Sukwika (2018b), the change of vegetated land into built-up land continues in Bogor, this is in line with the increase in the number of local residents and the demand for urban land (Siregar \& Sukwika, 2007), therefore, the function of land as community forests is increasingly disrupted.

The education level of the forest community in Bogor is classified as low, amounting to $76.67 \%$ of the people who only have elementary and junior high school education. The population with elementary education is 40,519 (46.86\%), junior high school 25,776 people (29.81\%), high school education 11,638 people (4\%), and the level of the academy and tertiary education are 303 people $(0.35 \%)$. (Pramono, 2009 ) reported that $85.3 \%$ of the respondents in Cisarua Subdistrict had a low level of education (had attended elementary school) and $8.8 \%$ had attended school. This social situation fosters a poor perception of efforts to conserve the environment and empower local communities. The results of the study by Pramono and Aminah (2010) state that the livelihoods of community forests in Bogor were still dominated by dryland agriculture, fisheries, and agricultural labour activities by $39.36 \%$, private sector by $28.62 \%$, service sector by $21.62 \%$, trade sector by $9.41 \%$ and state civil apparatus by $0.9 \%$.

The role of the young productive workforce working in the community forestry sector in Bogor is very low at only $25.71 \%$, this sector is still dominated by a fairly old age workforce of $57.14 \%$. The level of formal education of smallholding forest farmers which is in the low category is $54.29 \%$ and the level of informal education which is in the low category is $92.86 \%$. The area of land owned/controlled by community forest farmers with a narrow category $(<0.5 \mathrm{ha})$ of $70 \%$. The average farmer income is about USD 187.5 month $^{-1}$ with the average family burden of 4 family members family head ${ }^{-1}$. The average community forest farmer in Bogor has quite high farming experience, which is above 10 years (Table 1). The observation of Ofoegbu et al. (2017) shows that socioeconomic characteristics of households such as farm husbandry skills, years of residence in the community and age influenced use of the forest resources.

Farmer's family income The source of farmers' income, if viewed by stratification of land area, shows that the more land cultivated, the more land-use for various types of plants (Figure 3). According to Saihani (2011), the area of land that is managed has an effect on the amount of income received by community forest owners, the more land area the greater the income received so as to be able to meet the needs of their families. Fikir et al. (2016) stated that significant variation was also found among income groups: households with higher total annual income obtain more forest income than those with lower income, but they are relatively less dependent on forest products. Besides, various socioeconomic factors were found to influence forest and land income and dependency.

In the forest farmer households that process land in the strata III group, they tend to use their land for agroforestry activities. Conversely, farmers in the strata I group are more balanced between land-use for timber and agroforestry. In the three strata groups, there was almost a common tendency, where farmers provided land-use allocation for agroforestry activities. In general, the contributions obtained from the results of agroforestry are very helpful in fulfilling daily needs. Dev et al. (2003) also emphasize on the access of poorer households to essential forest products for their subsistence. In fact, in most developing countries, desires on community forestry are markedly linked to meeting basic needs and serving subsistence purposes, and therefore the benefits to the community is achieved by extracting them directly from the forest (Glasmeier \& Farrigan, 2005). According to Suharjito et al. (2003), if the amount of contribution provided by agroforestry is 10 per cent of the total income of agroforestry activities then it is considered very helpful in meeting needs.

Based on the results of a questionnaire survey of 70 respondents, data was obtained that the income of community forest farmers came from the main activities of farming with an average tenure of 0.17 ha and 0.45 ha of arable land and additional income from buying and selling (warung), farm labourers, and other additional income. The income of the farmer's family (with the number of members of 4 people) is an average of USD192.5 month ${ }^{-1}$. The lowest income is $\mathrm{USD}$ 7.50 month ${ }^{-1}$ and a maximum of USD236 month ${ }^{-1}$. This average income is still below the 2018 Bogor UMR (regional minimum wages) value of USD376.34 month $^{-1}$. This is caused by the limited land owned and cultivated land only covering an area of 0.31 ha $(<0.5 \mathrm{ha})$.

Farmers' income with land ownership of 1.0 ha from sengon (Paraserianthes falcataria) wood averaged USD45.2 month $^{-1}$, mahogany (Swietenia mahagoni) USD15.3 month $^{-1}$, and africa (Maesopsis eminii) USD6.7 month ${ }^{-1}$. Farmers' income from cultivating food crops (rice, sweet potatoes, 
Table 1 Attributes of community forest farming communities

\begin{tabular}{|c|c|c|c|}
\hline \multirow[t]{2}{*}{ Description } & \multirow[t]{2}{*}{ Category } & \multicolumn{2}{|c|}{ Total } \\
\hline & & $\mathrm{n}$ & $\%$ \\
\hline \multirow[t]{3}{*}{ Age } & Youth $(<41$ years $)$ & 18 & 25.71 \\
\hline & Middle age ( $41-56$ years) & 40 & 57.14 \\
\hline & Old age $(>57$ years $)$ & 12 & 17.14 \\
\hline \multirow[t]{2}{*}{ Total } & & 70 & \\
\hline & Low $(<9$ years $)$ & 38 & 54.29 \\
\hline \multirow[t]{2}{*}{ Formal education } & Medium (10-12 years) & 21 & 30.00 \\
\hline & $\operatorname{High}(>12$ years $)$ & 11 & 15.71 \\
\hline \multirow[t]{2}{*}{ Total } & & 70 & \\
\hline & Low $(<29$ hours $)$ & 65 & 92.86 \\
\hline \multirow[t]{2}{*}{ Non-formal education } & Medium (30-59 hours) & 5 & 7.14 \\
\hline & $\operatorname{High}(>60$ hours $)$ & 0 & 0.00 \\
\hline \multirow[t]{2}{*}{ Total } & & 70 & \\
\hline & Low $(<5$ years $)$ & 4 & 5.71 \\
\hline \multirow[t]{2}{*}{ Farming Experience } & Medium (5-10 years) & 18 & 25.71 \\
\hline & $\operatorname{High}(>10$ years $)$ & 48 & 68.57 \\
\hline \multirow[t]{2}{*}{ Total } & & 70 & \\
\hline & Narrow $(<0.5$ ha $)$ & 49 & 70.00 \\
\hline \multirow[t]{2}{*}{ Land area } & Medium $(0.5-1.0 \mathrm{ha})$ & 15 & 21.43 \\
\hline & Wide $(>1.0 \mathrm{ha})$ & 6 & 8.57 \\
\hline \multirow[t]{2}{*}{ Total } & & 70 & \\
\hline & Low (< USD 150) & 23 & 32.86 \\
\hline \multirow[t]{2}{*}{ Income } & Medium (USD 150-225) & 38 & 54.29 \\
\hline & High $(>$ USD 225) & 9 & 12.86 \\
\hline Total & & 70 & \\
\hline \multirow[t]{3}{*}{ Number of family } & Small $(<3$ people $)$ & 11 & 15.71 \\
\hline & Medium (3-5 people) & 36 & 51.43 \\
\hline & Large (> 5 people) & 23 & 32.86 \\
\hline Total & & 70 & \\
\hline
\end{tabular}

\section{$22.37 \%$}

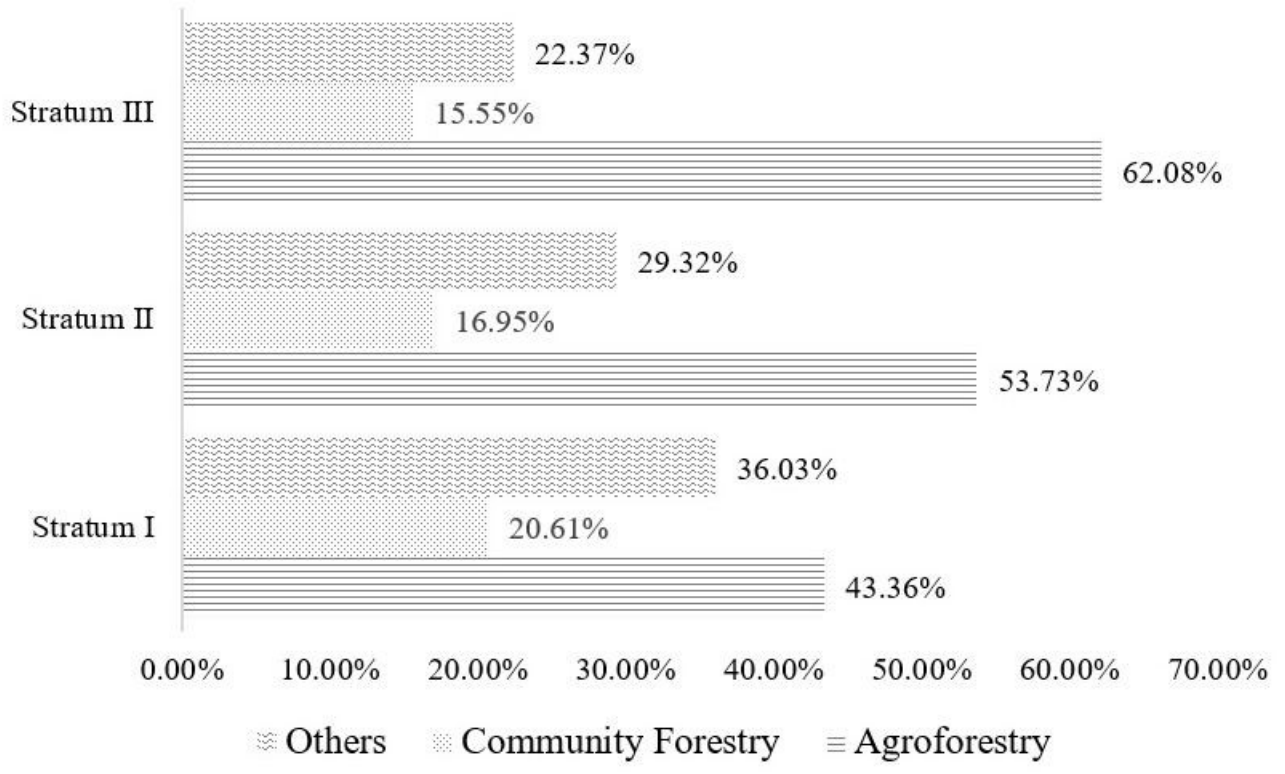

Figure 3 Contribution of the source of income to community forest farmer households. 
cassava) averaged USD48.55 month ${ }^{-1}$. The income from vegetable farming and fruit is an average of USD56.5. The income of farmer families who conduct a business shop with a size of $23 \mathrm{~m}^{2}$ at USD41 month ${ }^{-1}$, and become farm labourers of USD45 month ${ }^{-1}$. Another productive activity is to do 510 goat breeding activities and $510 \mathrm{~m}^{2}$ size ponds, each earning an average of USD66 month ${ }^{-1}$ and USD53.5 month $^{-1}$. The sources of farmers' income are presented in Table 3.

The income of these farmer households is still below the minimum physical requirement (KFM) to meet basic consumption needs of USD1,088 year ${ }^{-1}$ or USD90.7 month $^{-1}$. This income is also below the regional minimum wage (UMR) of Bogor in 2018, which is USD376.34 month $^{-1}$. Decent living needs (KHL) for families with 4 (four) members amounting to USD272 year ${ }^{-1}$ or USD226.7 month $^{-1}$. The calculated value of KHL per capita is calculated based on the expenditure of community households equal to the value of $800 \mathrm{~kg}$ of rice person ${ }^{-1}$ year $^{-1}$ based on the average benchmark price for minimum physical needs (KFM) of 320 $\mathrm{kg}$, education, health, and social respectively $161.31 \mathrm{~kg}$ (Sinukaban, 2007). The level of income when compared with the values of KFM and KHL, the community forest farmers community in Bogor can be classified as a condition that is less prosperous. The KHL analysis of Bogor farmers is presented in Table 4.

Farmers' income is spent on eight main needs, namely purchasing food staples $(58.05 \%)$, operational costs for school children (20.13\%), PLN electricity (8.01\%), procurement of clothing $(2.07 \%)$, health maintenance $(6.43 \%)$, social activities $(3.07 \%)$, home improvement $(1.22 \%)$, and purchase of hoe farming equipment and other $(1.02 \%)$. Most of the income of farmer households is spent on meeting basic food needs and operational costs of school children.

Community forest farmer group Based on data from the fisheries and forestry agricultural extension centre (BP3K) community forest farmer groups (KTHR) in Bogor there were 312 farmer groups and spread in 12 sub-districts. BP3K is an extension institution at the sub-district level formed by the government as a centre of excellence for farmers by extension workers in the field. Farmer groups are engaged in agriculture and forestry. In Bogor, forestry activities include timber products such as sengon ( $P$. falcataria), mahogany $(S$. mahagoni), afrika (Maeosopsis eminii), etc., and non-wood such as nutmeg, coffee, cloves, and others. Activities in the forestry sector also include fertilizer-making activities for making forest nurseries, making terraces, agroforestry and conserving other lands and water. Based on the type of business, soil conservation activities include vegetative activities and civil engineering.

Agricultural activities are cultivated in the form of food crops such as crops, rice, cassava, sweet potatoes, and others. Livestock activities and inland fisheries in the form of raising goats and carp, and cultivating mushrooms, organic grass, elephant grass, and others. The findings of this study echo those of Gill et al. (2010) and Abrams and Bliss (2013), state that amenity landowners continued, broadly, to institute land-use characteristic of traditional productivist practices: farming, livestock grazing, and timber harvesting.

The number of farmer groups who are interested in vegetative activities is as many as 312 farmer groups, while the number of farmer groups is interested in civil engineering activities as much as 1 farmer group. Farmers who join forest farmer groups are grouped by level of ability, namely the beginner, intermediate, middle and main groups (Table 5). The results of field observations indicate that there are several farmer groups that are active and independent in their activities, some farmer groups that show a less active attitude, and there are also several other farmer groups just waiting and becoming a place to accommodate government programs. According to Means et al. (2002), decisionmaking is often based on collaboration, with a consensus emerging from wide-ranging discussions, often fostering local reconciliation.

Landowners from outside the village The community groups that own land domiciled outside the forest area dominate land ownership of almost $70-80 \%$ with an average area of $0.5-2$ ha. Most of these community groups come from Jakarta. The land owned by this group is spread in

Table 4 The necessities of life are worthy of community forest farmers the necessities of life are worthy of community forest farmers

\begin{tabular}{|c|c|c|c|c|c|c|c|c|}
\hline No & Expenditures type & $\%$ & $\begin{array}{l}\text { Rice } \\
(\mathrm{kg})\end{array}$ & $\begin{array}{c}\text { Price of } \\
\text { rice* } \\
\text { (USD } \\
\left.\mathrm{kg}^{-1}\right)\end{array}$ & $\begin{array}{c}\text { Expendi- } \\
\text { tures } \\
\text { (USD } \\
\text { Fam }^{-1} \\
\text { Year }^{-1} \text { ) }\end{array}$ & $\begin{array}{l}\text { Number } \\
\text { of family } \\
\text { members }\end{array}$ & $\begin{array}{l}\text { Needs } \\
\text { (USD } \\
\text { Fam }^{-1} \\
\text { Year }^{-1} \text { ) }\end{array}$ & $\begin{array}{c}\text { Needs } \\
\left(\text { USD }^{-}\right. \\
\text {Fam }^{-1} \\
\text { Month }^{-1} \text { ) }\end{array}$ \\
\hline \multirow[t]{2}{*}{$a$} & $b$ & $c$ & $d$ & $e$ & $f$ & $g$ & $h$ & $i$ \\
\hline & & $\% d$ & & & $d \times e$ & & $e \times f$ & $f / 12$ \\
\hline 1 & KFM & 100 & 320 & 0.71 & 227.2 & 4 & 161.31 & 18.9 \\
\hline 2 & Education & 50 & 160 & 0.71 & 113.6 & 4 & 80.66 & 9.5 \\
\hline 3 & Health & 50 & 160 & 0.71 & 113.6 & 4 & 80.66 & 9.5 \\
\hline 4 & Social, saving, etc. & 50 & 160 & 0.71 & 113.6 & 4 & 80.66 & 9.5 \\
\hline 5 & KHL & 250 & 800 & 0.71 & 568.0 & 4 & 403.28 & 47.3 \\
\hline
\end{tabular}

Note: *) Average price of consumption (medium) rice in Bogor 2018 
several districts, such as in Babakanmadang, Sukaraja, Leuwiliang, Dramaga, Ciawi, and Cisarua Sub-Districts. With the high access to transportation, the area in these subdistricts forms a series of settlements or housing and has connected settlement/public housing activities along the Bogor-Jakarta route. Sukwika (2018a) stated that lands belonging to people outside the community forest area are generally used for settlement construction, vegetable cultivation, fruits, medicinal and ornamental plants, and economic value activities. Before the land is used by the owner for residential buildings, generally the land is not cultivated and neglected (idle land) so that it becomes empty land or becomes shrubs and reeds. Land controlled by people outside the forest area in the form of land owned. Some of the lands are entrusted to guards or cultivators, and some are directly controlled by the owner. Peluso (1992) reminded that secure property rights are often a crucial element in creating clear expectations and thereby reducing conflict. But the distribution of property rights also matters. Highly unequal property rights that deprive many people of even the basic means of subsistence can also lead to conflict. This condition is a challenge for policymakers to formulate development models in the natural resource sectors can link with complementary efforts to strengthen the underlying role of equitable governance and secure rights as a foundation for resilient livelihoods (Ratner, 2013). Bohle and Fünfgeld (2007) and Cronkleton et al. (2008) emphasize the concept of a political ecology approach, which emphasizes the positive potential of conflict to spawn social movements or institutional changes that lead to more socially equitable forms of resource use.

Local action arena In 2012, around 20,000 ha of forest land in Bogor were severely damaged, including community forests. Community forest land in Bogor is spread in 40 subdistricts, 18 Sub-Districts are in a severe category and the worst damage occurs in the western region, precisely in the Cisarua District upland area. Damage generally occurs as a result of land-use change and the increase in villa buildings or hotels that convert forest land into residential land, in addition to the many illegal buildings that are the main cause of forest destruction. The natural beauty and coolness of the area is a special attraction, so many build buildings for resting or other commercial buildings. The proximity and ease of accessibility from and to Jakarta, such as Babakanmadang, Bojonggede, Ciawi, Cileungsi, Dramaga, Jonggol and Parung Sub-Districts, were the reasons for the conversion of community forest land in the region. According to Verbist et al. (2004) the drivers of land-use change are distinguished by external and internal factors, population growth as external variables and road and infrastructure development (Siregar \& Sukwika, 2007), collection of levies or taxes, and land tenure arrangements as internal variables.

Environmental damage is a major cause of increased natural disasters such as floods and landslides in a number of areas. Ironically, the ecological destruction caused by forests and watersheds is exploited without control (Kahn, 2005; Hidayat, 2008). The shift in the function of community forests also makes the surrounding area prone to landslides, although there are indeed community forest areas in several sub-districts of Bogor that have been categorized as landslides. The results of the Herawati (2010) study based on the class of TBE (erosion hazard level) 5 showed that there were 10 Sub-Districts identified as having land areas with very heavy erosion hazard levels, four of which were Pamijahan (80 ha), Ciawi (8 ha), respectively. Cigombong (7 ha), Dramaga (4 ha), Leuwiliang (3 ha). As for the land with the TBE 4 category, 3 of the 16 Sub-Districts identified

Table 5 Data recapitulation of forest farmer groups

\begin{tabular}{lrrrrrrr}
\hline \multirow{2}{*}{ BP3K/Groups } & \multicolumn{9}{c}{ Level of group ability } & Total & $\begin{array}{c}\text { Number of } \\
\text { members }\end{array}$ \\
\cline { 2 - 5 } Cariu & B & A & I & M & & 868 \\
Jonggol & 18 & 16 & 3 & 0 & 37 & 1,676 \\
Gunung Putri & 8 & 22 & 14 & 0 & 44 & 248 \\
Cibinong & 13 & 1 & 1 & 0 & 15 & 1,018 \\
Ciawi & 14 & 40 & 7 & 1 & 62 & 524 \\
Caringin & 8 & 8 & 2 & 0 & 18 & 885 \\
Dramaga & 18 & 7 & 0 & 0 & 25 & 375 \\
Cibungbulang & 10 & 4 & 2 & 0 & 16 & 892 \\
Leuwiliang & 1 & 21 & 9 & 0 & 31 & 1,051 \\
Cigudeg & 4 & 14 & 2 & 1 & 21 & 614 \\
Parung Panjang & 4 & 11 & 0 & 0 & 15 & 587 \\
Ciseeng & 6 & 10 & 0 & 0 & 16 & 243 \\
\hline Total & 3 & 6 & 2 & 1 & 12 & 8,981 \\
\hline
\end{tabular}

Note: B: Beginner group, A: Advanced group, I: Intermediate group, M: Main group 
as having a land area with severe erosion are Caringin (200 ha), Dramaga (10 ha), Ciomas (5 ha). In these Sub-Districts so that heavy erosion potential can be reduced, it is necessary to take soil conservation measures and improve soil management, not the other way around, land conversion on the basis of economic value. Change or conversion of forest areas into other forms of use (deforestation) that have high economic values such as agriculture (Ewers, 2006) and residential area development (Jorgenson \& Burns, 2007; Nasendi, 2000). Verbist et al. (2004) and Yusuf (2004) indicate that damage to forest areas is caused by several factors, one of which is the problem of changing (transferring) forest areas into other areas. Changes in forest areas can be in the form of changes in designation, namely in the form of exchanging forest areas and releasing forest areas, for the benefit of plantations, transmigration settlements, industries, housing, offices and so on. The change in the function of the forest area is to change the function of the forest area for interests outside the forestry sector (Maladi, 2013). In addition, there is another form, namely the use of forest areas known as forest use loan permits (Siombo, 2014).

Transfer of community forest land ownership The transfer of land ownership in community forests involves the role of a land broker or a local term called biyong. Biyong generally comes from the local village community, although there are also those from outside the village but still within the community forest area. Biyong has an active role in finding information on land that will be sold by local people and seeking information on potential buyers from outside the community forest. In its development, in the 2000s, the share of sales commissions (fees) for biyong averaged $2.5 \%$ of buyers and also requested a number of voluntary commissions from the buyers. According to Sukwika (2018a), there are some biyong who use the scheme, if there is a seller offering a certain price, for example, USD10 $\mathrm{m}^{-2}$, then offered to the buyer with a selling price of USD20 or greater than the original price. With the increase in the price offered by biyong, biyong asks for a portion of the voluntary sales commission of $0-2.5 \%$ from the seller. Administrative arrangements to complete the sale and purchase agreement starting from RT/RW to Sub-Districts reached 2.5-5\% of the sales value of the land. The role of RT/RW, village to SubDistrict is to make a statement that the land being traded is not in dispute with other parties. This certificate is generally a guarantee to the buyer that the land to be traded is safe to buy. The role of biyong is very important in land ownership, which is to help find buyers for the local community, find land to be bought by the buyer, and provide security guarantees for the land that is traded to the buyer. While Fisher et al. (2018) suspected that land conversion was easy because of flawed land administration processes, entrenched political-economic interests among local actors, and lack of institutional engagement beyond the permitting process. Mendham and Curtis (2010) examine the phenomenon of turnover in rural property ownership by certain actors. Its findings in the form of sales records and spatially referenced rural landholder survey data. Mendham and Curtis (2010) stated that new property owners are significantly different from longer-term landholders in that they own smaller properties; are less likely to be farmers by occupation; are more likely to value conservation over agricultural production, and are less likely to adopt recommended sustainability practices.

The level of ownership of land owned and cultivated land by the outside community is wider $(70-80 \%)$ than the ownership of local communities (20-30\%). Communities outside make decisions in managing land owned in community forests. The outside community is more powerful in controlling the behaviour of local farmers who work on their land or they allow their land to become idle land. Gill et al. (2010) state that amenity ownership of rural lands by outside community often implies a blurring of production, consumption, and protection practices rather than a wholesale eclipse of production. Research by Chomba et al. (2015) in community forests found that national forest policies and actors transferred minimal powers that enabled local communities to execute forest protection and conservation roles while maintaining legislative powers and control of economic benefits centrally. Responding to the conditions above, L'Roe and Rissman (2017) considers the need for a partnership strategy in the form of joint forest management (Rangan \& Lane, 2001) with local communities. Investor partnership strategies and conservation programs can be shaped by the provision of forest benefits during ownership transitions.

Local rules with existing wisdom and land-use rules from the government are no longer able to direct the behaviour of farmers properly. Demand for agricultural commodities and demand for land for villa settlements or tourism businesses has reduced farmland capital and changed the behaviour of farmers to be not conservative. Such conditions cause land resources and water sources to decline. According to Putzel et al. (2015) that development policy, formalization frequently based on current social and environmental norms. However, its adoption is often unsuccessful and entails risks including leakage, barriers to small or poor actors, and negative effects on marginalized groups.

Poor environmental quality due to the neglect of problems and environmental impacts in forest development is a major factor in environmental disasters that affect the unsustainable social and economic quality (Rahman et al., 2017; Kusmana \& Sukwika, 2018). This places the level of vulnerability of the region to environmental disasters even greater. A study conducted by Skulska et al. (2019) stated that community-based forestry is faced with environmental challenges such as degradation, wildfires and loss of biodiversity. Resolution of these challenges is urgently needed at the legal, administrative and local levels. While (Rangan and Lane (2001) highlighted that forest access and ownership made by indigenous communities that have been historically disadvantaged and marginalized from the benefits of mainstream social and economic development. The problem can be approached with joint forest management (JFM). There are three concepts JFM approach scheme are access, control, and substantive democracy to assess the relative strengths and weaknesses of institutional 
processes that aim to engage in the sustainable management of forest resources.

Farm owner and farm labourers Farmers owning land in community forests in Bogor plant areas with wood species such as sengon ( $P$. falcataria), jabon (Anthocephalus cadamda), mahogany (S. mahagoni), afrika (M. eminii), teak (Tectona grandis), and mixtures. The community is interested in the ownership rights of forest areas, especially for planting sengon plants because of the benefits of economic value that can be obtained in it and others. Sengon wood species are chosen by farmers because their cultivation has been mastered for generations, has a relatively short life cycle ( 58 years) and has a clear market. Farmers usually sell sengon in the form of stands and several types of annual crops such as durian, mangosteen, rubber, coconut, petai, clove and others, besides that there are also rice and secondary crops.

Communities that have community forest land play an important role in making decisions about the land they have. Then, if farmers owning community forests have been incorporated into community forest farmer groups, then in relation to decisions in the exploitation of community forests, the farmer's family is the most decisive party. In community forestry, direct forest users are expected play an important role in the common decision making procedures and implementation of forestry activities (Boon, 2000; Charnley \& Poe, 2007; Pramono \& Aminah, 2010; Maryudi et al., 2012; Sukwika, 2018a). Families also have a dominant role in deciding whether their land will still be maintained as community forests or will be used for other uses. For example, the land originally designated as community forest was diverted to building houses, building infrastructure and other public facilities. Community forests are considered to have high economic, ecological and social values, therefore it is necessary to consider the existence of an institutional model that can play an effective role in preserving community forests, for example, the village government regulates the management of logging permits and the Bogor government controls development in its territory. Further according to Charnley and Poe (2007) that community forestry refers to forest management that has ecological sustainability and local community benefits as central goals, with some degree of responsibility and authority for forest management formally vested in the community.

Land ownership in community forest areas is not only owned by local communities, but also from people who live outside community forest areas, even $60 \%$ of land ownership rights are owned by people who live outside the community forest area. This community group plays a role in making decisions about the land owned and the land that it controls. Besides that, he also has an interest in controlling his land so that it is safe from other parties' claims (secure property right). In a community group, Putzel et al. (2015) stressed that they also contend with histories of ownership, access rights, market configurations, and practices attached to resources and the lands in which they are located.

The type of work of farm labourers in community forest areas is the highest occupancy after farmers. Farmers in community forests are generally farmers, of which there are also those who own their own land, usually less than 0.10 ha. Types of activities carried out by farmworkers starting from land clearing, planting and harvesting. The existence of these community groups is the driver of the implementation of agroforestry activities in community forest areas. Farm workers are often involved because of shortages of labour from within the family. The labour costs of farm labourers in community forests are in accordance with community recognition of USD2.5-3.5 day . $^{-1}$.

The level of welfare of the local community On the economic aspect, farmers' land tenure in the form of land owned by 0.17 ha and 0.45 ha of arable land only earn an average income of USD231 year ${ }^{-1}$ or USD192.5 month $^{-1}$. This average income is still below the 2018 Bogor regional minimum wage value of USD376.34 month ${ }^{-1}$. This is caused by the limited land owned and cultivated land only covering an area of 0.31 ha $(<0.5$ ha). The standard of decent living needs (KHL) for families with 4 (four) members is USD272 year $^{-1}$ or USD226.7 month ${ }^{-1}$. The value calculated from the KHL per capita is calculated based on the expenditure of the community household equal to the value of $800 \mathrm{~kg}$ of rice person $^{-1}$ year $^{-1}$ based on the average benchmark price for minimum physical needs (KFM) of $320 \mathrm{~kg}$, education, health and social respectively $160 \mathrm{~kg}$ (Sinukaban, 2007). Based on the level of income, when compared with the values of KFM and KHL, the community forest farmers in Bogor can be classified as under-prosperous.

For smallholding forest farmers, community forestry businesses generally become the main source of income. Farmers' household income can reflect their household economic condition. The high and low level of household income can be used as one indicator of the level of welfare of a household. The level of income is influenced by the number of types of business carried out by farmers. Tree ownership also creates more permanent rights to farmland and is prestigious in the community. (Khususiyah et al., 2010; Maryudi et al., 2012; Rahman et al., 2017; Sukwika et al., 2016; Sukwika et al., 2018). Farmers' income in the community forest area of Bogor comes from income sources in the form of: timber products averaging USD22.4 month ${ }^{-1}$ for ownership of an area of $1.0 \mathrm{ha}$, food crops on average

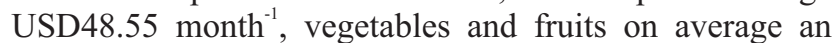
average of USD6.5 month ${ }^{-1}$, a house stall business with a size of $23 \mathrm{~m}^{2}$ of USD45 month $\mathrm{m}^{-1}$, and being a farm laborer of USD45 month ${ }^{-1}$. Other productive activities from raising 510 goats and $510 \mathrm{~m}^{2}$ ponds each earn an average of USD66 month $^{-1}$ and USD53.5 month ${ }^{-1}$.

Referring to the income from some of these farming activities, farmers in community forests can be classified as poor or not prosperous. With these poor conditions, the behaviour of farmers is not able to finance their family members to continue their education to a higher level. Current conditions, according to data from 70 respondents, the education level of community forests are classified as low educated with the majority of elementary and junior high school education $(84.29 \%)$. With narrow land 
ownership, low education, and relatively small family income, the tendency of community behaviour in farming is more exploitative.

\section{Conclusion}

The institutional of local community is classified as weak because it is not effective in regulating community behavior to achieve the objectives of community forest management, including economic, social, and ecological goals, this condition indicated by the low performance achieved in community welfare and forest exploitation that occurs. Ownership of land resources is very low and even almost does not own land, the level of welfare of local people can be categorized as poor people, and public education is relatively low. The most significant contribution to the income sources of smallholder forest farmers comes from the agroforestry sector. However, the challenge for the community forest farmer families is that the level of expenditure of the farm family is still higher than the monthly income. The number of dependents is relatively high, making it difficult for them to have family savings. Based on the results of strata analysis of land ownership rights by community forest farmers, $70 \%$ of farmers are in the third strata, namely land ownership less than 0.5 ha, and $41.56 \%$ of community forest farmer groups classified as landowners.

\section{Acknowledgment}

We wish to thank a number of institutions and individuals. We are also grateful to many families and individuals of farmers groups in Bogor who participated and shared their ideas. Finally, thanks to the reviewers for their valuable comments on the manuscript and thank the editorial team for its support.

\section{References}

Abrams, J., \& Bliss, J. C. (2013). Amenity landownership, land use change, and the re-creation of "working landscapes". Society \& Natural Resources: An International Journal, 26(7), 845-859. https://doi.org/ $10.1080 / 08941920.2012 .719587$

[BKP5K] Badan Ketahanan Pangan dan Pelaksana Penyuluhan Pertanian, Perikanan dan KehutananKabupaten Bogor. (2014). Rencana strategis tahun 20132018 Badan Ketahanan Pangan dan Pelaksana Penyuluhan Pertanian, Perikanan dan Kehutanan (BKP5K). Bogor: Dinas Pertanian dan Kehutanan Kabupaten Bogor.

Bohle, H.G., \& Fünfgeld, H. (2007). The political ecology of violence in eastern Sri Lanka. Development and Change, 38(4), 665-687. https://doi.org/10.1111/j.1467-7660. 2007.00428.x

Boon, T. E. (2000). Conceptualisation and evaluation of participation in danish state forest management. [dissertation]. Copenhagen: Royal Veterinary and Agricultural University.

Charnley, S., \& Poe, M. R. (2007). Community Forestry in
Theory and Practice: Where are we now? Annual Review of Anthropology, 36, 301-336. https://doi.org/10.1146/ annurev.anthro.35.081705.123143

Chomba, S. W., Nathan, I., Minang, P. A., \& Sinclair, F. (2015). Illusions of empowerment? Questioning policy and practice of community forestry in Kenya. Ecology and Society, 20(3), 1-11. https://doi.org/10.5751/ES07741-200302

Cronkleton, P., Stone-Jovicich, S., Schmink, M., Taylor, P.L., \& Barry, D. (2008). Environmental Governance and the Emergence of Forest-Based Social Movements. CIFOR Occasional Paper No. 49. Bogor: Center for International Forestry Research.

Dev, O. P., Yadav, N. P., Springate-Baginski, O., \& Soussan, J. (2003). Impacts of community forestry on livelihoods in the middle hills of Nepal. Journal of Forest and Livelihood, 3(1), 6477.

Di Gregorio, M., Hagedorn, K., Kirk, M., Korf, B., N. McCarthy, N., \& Meinzen-Dick, R. (2008). Property rights, collective action, and poverty: The role of institutions for poverty reduction. CAPRi Working Paper No. 81. Washington, DC: International Food Policy Research Institute.

Ewers, R. M. (2006). Interaction effects between economic development and forest cover determine deforestation rates. Global Environmental Change, 16(2), 161-169. https://doi.org/10.1016/j.gloenvcha.2005.12.001

Fikir, D., Tadesse, W., \& Gure, A. (2016). Economic contribution to local livelihoods and households dependency on dry land forest products in Hammer District, Southeastern Ethiopia. International Journal of Forestry Research, 2016, 1-11. https://doi.org/10.1155/ $2016 / 5474680$

Fisher, M. R., Moeliono, M., Mulyana, A., Yuliani, L., Adriadi, A., Kamaluddin, ..., \& Sahide, M. A. K. (2018). Assessing the new social forestry project in Indonesia: Recognition, livelihood and conservation? International Forestry Review, 20(3), 346-361. https://doi.org/ $10.1505 / 146554818824063014$

Gill, N., Klepeis, P., \& Chisholm, L. (2010). Stewardship among lifestyle oriented rural landowners. Journal of Environmental Planning and Management, 53(3), 317-334. https://doi.org/10.1080/09640561003612890

Glasmeier, A. K., \& Farrigan, T. (2005). Understanding community forestry: A qualitative meta-study of the concept, the process, and its potential for poverty alleviation in the United States case. The Geographical Journal, 171(1), 56-69.

Herawati, T. (2010). Spatial analysis of erosion hazard level in the Cisadane watershed area of Bogor Regency. Journal of Forest and Nature Conservative Research, 
7(4), 413-424. https://doi.org/10.20886/jphka.2010.7. 4.413-424

Hidayat, H. (2008). Politik lingkungan: Pengelolaan hutan masa orde baru dan reformasi. Jakarta: Yayasan Obor Indonesia.

Jorgenson, A. K., \& Burns, T. J. (2007). Effects of rural and urban population dynamics and national development on deforestation in less-developed countries, 1990-2000. Sociological Inquiry, 77(3), 460-482. https://doi.org/ 10.1111/j.1475-682X.2007.00200.x

Kahn, J. R. (2005). The economic approach to environmental and natural resources. Ohio: Thomson/South-Western.

Khususiyah, N., Buana, Y., \& Suyanto. (2010). Community forestry: Efforts to improve welfare and equitable distribution of farmers' income around the forest. Bogor: World Agroforestry Centre.

Kusmana, C., \& Sukwika, T. (2018). Coastal community preference on the utilization of mangrove ecosystem and channelbar in Indramayu, Indonesia. AACL Bioflux, 11(3), 905-918.

L'Roe, A. W., \& Rissman, A. R. (2017). Changes in Wisconsin's large private forests, 1999-2015: Land ownership, conservation, and recreational access. Society \& Natural Resources, 30(1), 63-78. https://doi.org/10. 1080/08941920.2016.1180729

Maladi, Y. (2013). Critical legal study of capitalist-oriented forest conversion. Jurnal Dinamika Hukum, 13(1), 109-123. https://doi.org/10.20884/1.jdh.2013.13.1.160

Mardikanto, T. (1996). Penyuluhan pembangunan kehutanan. Surakarta: Departemen Kehutanan dan Fakultas Pertanian UNS.

Maryudi, A., Devkota, R. R., Schusser, C., Yufanyi, C., Sall, M., Aurenhammer, H., ..., \& Krott, M. (2012). Back to basics: Considerations in evaluating the outcomes of community forestry. Forest Policy and Economics, 14(5), 1-5.https://doi.org/10.1016/j.forpol.2011.07.017

Means, K., Josayma, C., Nielsen, E., \& Viriyasakultorn, V. (2002). Community based forest resource conflict management: A training package. Rome: Food and Agriculture Organization of the United Nations.

Mendham, E., \& Curtis, A. (2010). Taking over the reins: Trends and impacts of changes in rural property ownership. Society \& Natural Resources, 23(7), 653-668. https://doi.org/10.1080/08941920801998893

Nasendi, B. D. (2000). Deforestation and forest policies in Indonesia. In M. Palo \& H. Vanhanen, World forests from deforestation to transition? (pp. 167-182). Dordrecht: Kluwer Academic Publisher. https://doi.org/10.1007/ 978-94-010-0942-3_9
Oakerson, R. J. (1992). Analyzing the commons: A framework. In D. W. Bromley, Making the commons work. San Francisco: ICS Press.

Ofoegbu, C., Chirwa, P., Francis, J., \& Babalola, F. D. (2017). Socio-economic factors influencing household dependence on forests and its implication for forestbased climate change interventions. Southern Forests: a Journal of Forest Science, 79(2), 109-116. https://doi. org/10.2989/20702620.2016.1255420

Ostrom, E. (2005). Understanding institutional diversity. Princeton: Princeton University Press.

Peluso, N. L. (1992). Rich forests, poor people: resource control and resistance in Java. Berkeley: University of California Press.

Poteete, A. R., Janssen, M. A., \& Ostrom, E. (2010). Working together: Collective action, the commons, and multiple methods in practice. Princeton: Princeton University Press

Pramono, A. A. (2009). Forest environmental services for local communities in the Ciliwung Hulu watershed. Jurnal Penelitian Sosial dan Ekonomi Kehutanan, 6(1), 39-51.https://doi.org/10.20886/jpsek.2009.6.1.39-51

Pramono, A. A., \& Aminah, A. (2010). Analisis faktor yang berpengaruh terhadap keputusan rakyat untuk mengkonversi hutan rakyat di DAS Ciliwung Hulu. Jurnal Penelitian Sosial dan Ekonomi Kehutanan, 7(3), 197-208.

Putzel, L., Kelly, A. B., Cerutti, P. O., \& Artati, Y. (2015). Formalization as development in land and natural resource policy. Society \& Natural Resources, 28(5), 453-472. https://doi.org/10.1080/08941920.2015. 1014608

Racevskis, L. A., \& Lupi, F. (2006). Comparing urban and rural perceptions of and familiarity with the management of forest ecosystems. Society \& Natural Resources, 19(6), 479-495. https://doi.org/10.1080/0894192060066 3862

Rahman, S. A., Jacobsen, J. B., Healey, J. R., Roshetko, J. M., $\&$ Sunderland, T. (2017). Finding alternatives to swidden agriculture: Does agroforestry improve livelihood options and reduce pressure on existing forest? Agroforestry Systems, 91(1), 185-199. https://doi.org/10. 1007/s10457-016-9912-4

Rangan, H., \& Lane, M. B. (2001). Indigenous peoples and forest management: Comparative analysis of institutional approaches in Australia and India. Society \& Natural Resources, 14(2), 145-160. https://doi.org/10.1080/0894 19201300000544

Ratner, B. D. (2013). Building resilience in rural livelihood systems as an investment in conflict prevention. In $\mathrm{H}$. Young, \& L. Goldman, Livelihoods, natural resources, 
and post-conflict peacebuilding. London: Earthscan.

Ratner, B. D., Meinzen-Dick, R., May, C., \& Haglund, E. (2013). Resource conflict, collective action, and resilience: An analytical framework. International Journal of the Commons, 7(1), 183-208. https://doi.org/ $10.18352 / \mathrm{ijc} .276$

Saihani, A. (2011). Factor analysis of socioeconomic on farmer's income in Sungai Durait Tengah village, Hulu Sungai Utara regency. Jurnal Ziraa'ah, 31(3), 219-225. https://doi.org/10.31602/zmip.v44i2

Schlager, E. \& Ostrom, E. (1992). Property rights regimes and natural resources a conceptual analysis. Land Economics, 68(3), 249-262. https://doi.org/10.2307/ 3146375

Sinukaban, N. (2007). Soil and water conservation, key to sustainable development. In F. Agus, Soil and water conservation. Jakarta: Masyarakat Konservasi Tanah dan Air.

Siombo, M. R. (2014). The responsibility of regional governments for environmental damage and its relation to licensing authority in the forestry and mining sectors. Jurnal Dinamika Hukum, 14(3), 394-405. https://doi. org/10.20884/1.jdh.2014.14.3.306

Siregar, H., \& Sukwika, T. (2007). Faktor-faktor yang mempengaruhi kinerja pasar tenaga kerja dan implikasi kebijakannya terhadap sektor pertanian di Kabupaten Bogor. SOCA: Jurnal Sosial Ekonomi Pertanian, 7(3), $1-22$.

Skulska, I., Colaço, M. C., Aggarwal, S., Didier, H., Monteiro, M. L., \& Rego, F. C. (2019). Assessment of Portuguese community forestry using the voluntary guidelines on the responsible governance of tenure and FAO community-based forestry framework. Society \& Natural Resources, 33(1), 101-121. https://doi.org/10. $1080 / 08941920.2019 .1660934$
Suharjito, D., Sundawati, L., Suyanto, S. R. U., \& Utami, A. (2003). Socio-economic and cultural aspects of agroforestry ( $5^{\text {th }}$ Ed.). Bogor: World Agroforestry Centre (ICRAF) Southeast Asia

Suharti, S. (2001). Increased community participation in forest management through the development of social forestry programmes in Indonesia. In P. J. M. Hillegers, \& H. H. Longh (Eds.), Proceedings of The Balance Between Biodiversity Conservation and Sustainable Use of Tropical Rain Forests (pp. 233-244). Wageningen: Tropenbos.

Sukwika, T. (2018a). Actor analysis in formulating institutional models for community-forest development in Bogor Regency. Journal of Regional and Rural Development Planning, 2(2), 133-150. https:// doi.org/10.29244/jp2wd.2018.2.2.133-150

Sukwika, T. (2018b). Peran pembangunan infrastruktur terhadap ketimpangan ekonomi antarwilayah di Indonesia. Jurnal Wilayah dan Lingkungan, 6(2), 115-130. https://doi.org/10.14710/jwl.6.2.115-130

Sukwika, T., Darusman, D., Kusmana, C., \& Nurrochmat, D. R. (2016). Evaluating the level of sustainability of privately managed forest in Bogor, Indonesia. Biodiversitas, Journal of Biological Diversity, 17(1), 241-248. https://doi.org/10.13057/biodiv/d170135

Sukwika, T., Darusman, D., Kusmana, C., \& Nurrochmat, D. R. (2018). Policy scenarios for managing of sustainability private-forests in Bogor Regency. Journal of Natural Resources and Environmental Management, 8(2), 207-215.https://doi.org/10.29244/jpsl.8.2.207-215

Verbist, B., Putra, A.E., \& Budidarsono, S. (2004). Penyebab alih guna lahan dan akibatnya terhadap fungsi daerah aliran sungai (DAS) pada lansekap agroforestri berbasis kopi di Sumatera. Jurnal Agrivita, 26(1), 29-38.

Yusuf, Y. (2004). Hukum lingkungan versus pembangunan nasional. Jurnal Respublica, 4(1), 97-109. 